\title{
MODIFICATION OF BAYAH BANTEN NATURAL ZEOLITE AS HETEROGENEOUS CATALYST IN BIODIESEL PRODUCTION
}

\author{
Rudi Hartono, Anondho Wijanarko, Heri Hermansyah* \\ Department of Chemical Engineering, Universitas Indonesia, Indonesia
}

\begin{abstract}
The purpose of this study was to produce a biodiesel through the reaction of waste cooking oil with methanol by using a modified Bayah Banten zeolite as catalyst. This catalyst was produced from its natural from by using potassium hydroxide $(\mathrm{KOH})$ as a reactant in $100 \mathrm{ml}$ of distilled water. The reaction to produce a biodiesel was performed at various temperature and time to get the optimum condition. The advantages of this catalyst were eco-friendly, easily separated after the reaction process, and can be reused as a catalyst. The molar ratio of waste cooking oil and methanol for transesterification process was 1:7. The yield of biodiesel at various optimum temperatures and times is $94 \%$ (50 gram of $\mathrm{KOH} / 100 \mathrm{ml}$ ), $87,8 \%$ (75 gram of $\mathrm{KOH} / 100 \mathrm{ml}$ ), and $86 \%$ (100 gram of $\mathrm{KOH} / 100 \mathrm{ml}$ ). Biodiesel results were analyzed by GC Ester content and modified catalysts were characterized using XRD, FTIR, and SEM-EDX.
\end{abstract}

Key words: A modified bayah banten zeolite, ion exchange catalyst, waste cooking oil

\section{INTRODUCTION}

Biodiesel is a mixture of alkyl ester and long chain fatty acid which is derived from renewable natural resource such as vegetables oil, animal oil and waste cooking oil which are expected to replace the existing petroleum diesel both through esterification and transesterification process [1]. ASTM International defines biodiesel as the mixture of ester monoalkilik, the length of the chain from fatty acid from renewable resource to be used as fuel of diesel machine. The mixture of diesel fuel is shown as "BX" in which " $X$ " is the percentage of biodiesel in the mixture. For example, "B5" shows the combination of $5 \%$ biodiesel and $95 \%$ of petro diesel, it means that B100 shows pure biodiesel.

Biodiesel has many advantages such as non-toxic with zero sulfur content, easily degraded, produces low carbon monoxide emissions, and non-combustible hydrocarbon binding agents [2]. Furthermore, biodiesels are renewable, biodegradable and have higher certain number than conventional diesels [3]. The oxygen content of biodiesel is higher than petro diesel where diesel engines denote to reduce of particulates emission, carbon monoxide, sulfur, polyaromatic, hydrocarbons, and smoke and noise [4].

Recently, the use of homogeneous catalysts is still dominant in biodiesel production; despite its limitation, problem of high cost, the difficulty of catalyst separation from the mixture, and high amounts of waste water produced occur during the purification of biodiesel [1] . The problem can be reduced by switching to the use of heterogeneous catalysts. It is more active, requiring lower temperatures, shorter reaction times and reuseable [3]. Heterogeneous catalyst is an alternative to homogeneous catalyst replacement because it is easy to separate and reuse. Heterogeneous catalyst shows a high potency, strong and long-lasting that can be used for utilizing free fatty acids up to $40 \%$ [5]. Heterogeneous catalyst used is the Bayah Banten zeolite modified.

[1] Heterogeneous Zeolite LTA catalysts using $\mathrm{NaOH}$ could be used to produce biodiesel with a temperature of $62.9^{\circ} \mathrm{C}$ and reaction time of 146 minutes with yield of biodiesel yield $(92.8 \pm 4.0) \%$. [6] Meanwhile, utilization of Zeolite/chitosan $/ \mathrm{KOH}$ produced $93 \%$ biodiesel at $1: 7$ molar ratios for 3 hours whereas. [2] Using natural impregnated zeolite by $\mathrm{KOH}$ as a heterogeneous catalyst to produce biodiesel, research was conducted at a temperature of $50^{\circ} \mathrm{C}$, as long as two hours, yielded $96.7 \%$ biodiesel. [7] Another method is to using an impregnated NAX catalyst using a $16 \% \mathrm{KOH}$ produced $(95.2 \pm 0.96 \%)$ biodiesel for 3 hours reaction and temperature $65^{\circ} \mathrm{C}$. [8] Using lithium metasilicate and mixed with $A B W$ zeolite as catalyst, produced biodiesel above $95 \%$ within one hour reaction time. Furthermore, the catalyst used can be recycled in three cycles in a row without deactivation. With the reduction of catalyst-to-oil loading up to $30 \%$ by weight, biodiesel yields can still be achieved. [9] using a heterogeneous synthesis of fly ash synthesis with Methanol and mustard oil to get the maximum conversion of $84.6 \%$ biodiesel, $5 \%$ catalyst weight a molar ratio (12:1) as long as 7 hours at $65^{\circ} \mathrm{C}$. The catalyst is reused for three usage cycles. [10] Modification of $\mathrm{FeCl}_{3}$ as a heterogeneous catalyst. Producing yield biodiesel $92 \%$, molar ratio $(10: 1)$, catalyst content $8 \%$ at $90^{\circ} \mathrm{C}$, reaction time $120 \mathrm{~min}$. [11] transesterification of biodiesel using gram $\mathrm{KOH} /$ zeolite as a heterogeneous catalyst. Variation of $\mathrm{KOH}$ concentration to get the maximum yield of biodiesel is $95.09 \%$ on impregnation of 100 grams of $\mathrm{KOH}$ in $100 \mathrm{ml}$ of aquadest for 2 hours, reaction temperature of $60^{\circ} \mathrm{C}$ and the molar ratio (1: 7), the catalyst used of $3 \%$ of palm oil. [12] Transesterification process of heterogeneous catalyst with methanol, with a molar ratio $(15: 1)$. Alumina catalyst with $35 \% \mathrm{KI}$ for 3 hours at a fixed temperature was dried at $393 \mathrm{~K}$ for 16 hours 
$\left(\mathrm{KI} / \mathrm{Al}_{2} \mathrm{O}_{3}\right)$ and calcined at $773 \mathrm{~K}$ for 3 hours, (1-5\%) the weight of the catalyst used, the biodiesel produced at optimum conditions is $95.2 \%$. [5] By using Chlorosulfonic-Circonia catalyst $\left(\mathrm{HClSO}_{3}-\mathrm{ZrO}_{2}\right)$ as a heterogeneous catalyst for making biodiesel with methanol and rice bran oil with free fatty acids (FFA) content (20-50\%). 92\% conversion was resulted at $120^{\circ} \mathrm{C}$, molar ratio (12:1), for 12 hours and $6 \%$ by weight of catalyst. [13] $\mathrm{Al}_{2} \mathrm{O}_{3}$ is modified $\mathrm{MgZnO}$ catalyst as catalyst (MgZnAlO) activated and studied for transesterificationof vegetable oil with methanol to produce biodiesel. The effect of parameters such as molar ratio, catalyst weight, reaction time and temperature was studied. Catalysts were reused for five cycles. The conversion of biodiesel produced was $98 \%$. [14] Heterogeneous catalysts used zeolite $\mathrm{NaX}$ and $\mathrm{KOH}$ to produce biodiesel using soybean oil. The best results were obtained by loading zeolite $\mathrm{NaX}$ at $10 \% \mathrm{KOH}$ at 24 hours impregnation. 339K temperature was dried for 3 hours. The yield of biodiesel was $85.6 \%$ at molar ratio $(10: 1)$, reaction time of 8 hours and, the catalyst used as much as $3 \%$ by weight of soybean oil. [15] Biodiesel production using various zeolite heterogeneous catalysts between ZSM-5 (MFI), Modernite (MOR), Faujasite (FAU), beta (BEA) zeolite and silica at the ratio of $\mathrm{Si} /$ Al molar ratio $(25,10,3,13)$. The best conversion results on HMFI (25) and HMOR (10). Optimum conversion produced $80 \%$ at $60^{\circ} \mathrm{C}$.

The heterogeneous catalyst in this study comes from the area of lebak Banten that is natural zeolite which has a three-dimensional frame structure which is a crystalline sillica alumina. The natural zeolite used has huge amount but the distribution is uneven and the chrystallinity is poor. To improve it, the activation and modification was conducted to increase its activation as a catalyst [16].This study focused on the modification process of Bayah Banten natural zeolite with the impregnation method using $\mathrm{KOH}$ and the calcination process to produce the catalyst. The catalyst produced was then reacted with waste cooking oil to produce biodiesel by transesterification process. The effect of concentration, temperature and reaction time was observed.

\section{MATERIAL AND METHODS}

\section{Material preparation}

Natural Zeolite was derived from nature of Bayah Banten, Banten Province, Indonesia. The existing zeolite was crushed firstly by using a hammer to obtain a size from 50 to 60 meshes. Waste cooking oil was obtained from Cilegon restaurant which had been used for three times. $\mathrm{KOH}$ was Made in Germany with index- No.019-002-00-8, Brand KGA, 6427 / Darmstadt Germany, Tel +49 (6) 615172-2440 EMD Millipore Corporation. Methanol Pro Analyse was made in Germany.

\section{Preparation of a modified Bayah Banten zeolite catalyst}

The zeolite was from the natural zeolite of Bayah Banten through the crushing stage, and then sieved (Screening) to get the desired diameter size. Activation of zeolite in nature of bayah Banten was done to modify the skeletal structure or non-zeolite framework in order to enhance its power. Activation zeolite was carried out physical and chemical treatment. The physical activation aimed to evaporate the water captured in the pores of the zeolite crystal that was carried out at a temperature of $110^{\circ} \mathrm{C}$ for 24 hours so that the surface area of the crystal pores increased. The chemical activation was performed by using a $\mathrm{KOH}$ solution to clean the pore surface, remove the impurity compound and rearrange molecule composition of zeolite. Impregnation is carried out using a $\mathrm{KOH}$ solution at a temperature of $60^{\circ} \mathrm{C}$, for 2 hours, inputting the oven to $60^{\circ} \mathrm{C}$ for 24 hours and separating it with a vacuum filter pump. Furthermore, the catalyst was calcined and dried in the oven at $110^{\circ} \mathrm{C}$ for 24 hours so that the obtained catalyst was relatively stable at high temperatures. The process was carried out by means of a heated zeolite temperature of $450^{\circ} \mathrm{C}$, 4 hours in calcination time, chill and the catalyst is ready for use. Calcination time for 4 hours [16]

\section{Characterization of material and catalyst}

Characterization of Bayah Banten natural zeolite cataly st was conducted by using several methods, such as using XRD brand MalvernPanalytical Empyrean Diffractometer, to analyze the type and composition of crystals of zeolite. FTIR was conducted to determine the functional groups present in the zeolite. FTIR analysis was performed on Shimadzum $840^{\circ} \mathrm{S}$ FTIR instrument in the range of $4000-500 \mathrm{~cm}$ brand thermo scientific seri Nicolet i5. Micrograph Electron Scanning Method (SEM-EDX) brand TESCAN was conducted to determine the composition of the potassium element of the crude zeolite, modified zeolite and zeolite used for the transesterification reaction.

\section{Method}

Research methodology is focused to the ion exchange engineering as a heterogeneous catalyst for biodiesel synthesis to obtain optimum result with various time, catalyst, and temperature by activating ion exchange used firstly,i.e. Bayah Banten natural zeolite (ZABBrht). The research was done in the Bioprocess Laboratory of Chemical Engineering Department, Engineering Faculty, Universitas Indonesia Depok 16424.

\section{RESULTS AND DISCUSSION}

\section{Characteristic of waste cooking oil}

Physical and chemical properties analysis were performed on cooking oil including density (ASTM D4052), kinematic viscosity(ASTM D445), free fatty acid content. The results of analysis characteristics of cooking oil could be seen in Table 1. 


\section{Catalyst characterization}

$X$-ray Diffraction $(X R D)$

Table 1: Characteristic of Waste Cooking Oil

\begin{tabular}{|c|c|}
\hline Characteristic & Amount \\
\hline Density at $25^{\circ} \mathrm{C}, \mathrm{kg} / \mathrm{L}$ & 9,0268 \\
\hline Kinematic viscosity at $23,4^{\circ} \mathrm{C}, \mathrm{Cst}$ & 40,67 \\
\hline Fatty acid content, $\%$ & 0,03 \\
\hline
\end{tabular}

Spectroscopic analysis of X-ray diffraction(XRD) is required to identify the zeolite crystallinity characteristic before and after impregnation. All materials contain specific crystal when analyzed with XRD will produce specific peaks. XRD analysis Difactogram resulted shows crystallinity level solids. Material and crystallinity are good if they have high peak incisive intensity and a good peak separation. Natural zeolite XRD spectrum (Figure 1 ) shows peaks of Bragg angle $(2 \theta) 10^{\circ}, 23,5^{\circ}, 26^{\circ}$, $31^{\circ}, 33^{\circ}, 37^{\circ}, 47^{\circ}, 59^{\circ}$ and $62,5^{\circ}$. This indicates the Bayah natural zeolite is klinoptilotit. High intensity peaks show Bayah natural zeolite having high crystallinity.

From Figure 2. Treatment of zeolite and $\mathrm{KOH}$ decreases or also damages zeolite crystallinity because of desilicate process, it is pointed by loss of high intensity peaks at $10^{\circ}, 23^{\circ}$, and $62,5^{\circ}$ Bragg angle to zeolite after base treatment. However, zeolite XRD spectrum after the treatment showed the significant new peaks especially

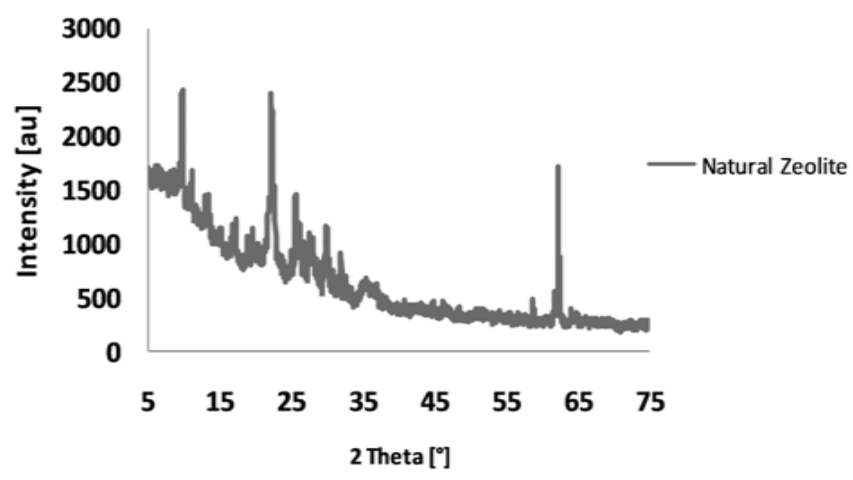

Figure 1: XRD Pattern Bayah Banten Natural Zeolite

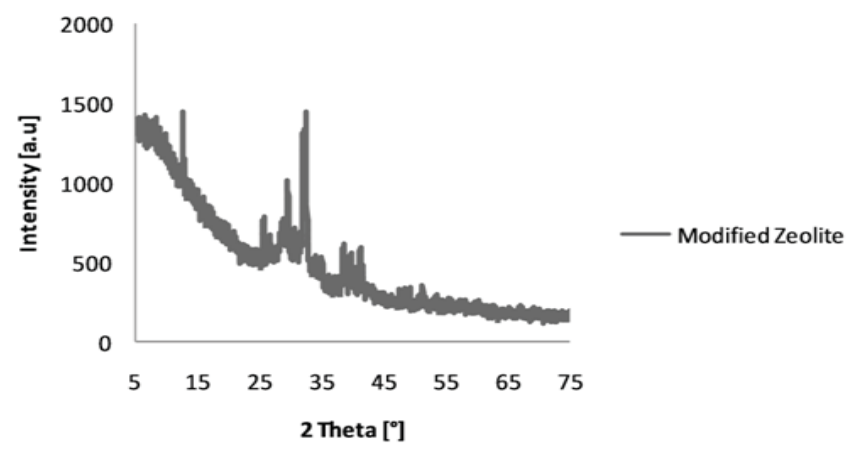

Figure 2: XRD Pattern Modified Bayah Banten Natural Zeolite at $12.5^{\circ}, 26^{\circ}, 29^{\circ}, 31^{\circ}, 33^{\circ}, 35^{\circ}, 38^{\circ}, 40^{\circ}, 41^{\circ}, 49^{\circ}$, and $51.5^{\circ}$ the Bragg angle providing from $\mathrm{K}_{2} \mathrm{O}$ oxide. $\mathrm{K}_{2} \mathrm{O}$ formation indicates $\mathrm{KOH}$ which is in the surface and zeolite matrix changing to $\mathrm{K}_{2} \mathrm{O}$ during the impregnation and calcination process. The impregnated $\mathrm{K}_{2} \mathrm{O}$ in zeolite can put up a high catalytic activity.

\section{FTIR}

Band in $3613,179 \mathrm{~cm}^{-1}$ and $1635,06 \mathrm{~cm}^{-1}$ wavenumbers indicates the $\mathrm{O}-\mathrm{H}$ cluster stretching vibration to silanol $(\mathrm{Si}(\mathrm{OH}) \mathrm{Al})$ and also water $(\mathrm{H}-\mathrm{O}-\mathrm{H})$. The most powerful band which appeared in $1016,116 \mathrm{~cm}^{-1}$ wave number indicating the asymetric stretching vibration of $\mathrm{TO}_{4}(\mathrm{~T}=\mathrm{Si}$, Al) tetrahedral, typical of zeolite (Intrapong Pisitpong et al, 2003). Absorption band in $788,15 \mathrm{~cm}^{-1}$ shows the symmetrical stretching vibration of Si-O-Al. Whereas band in $593,66 \mathrm{~cm}^{-1}$ is bending vibration of O-Si(Al)-O.

Tretament of zeolite and $\mathrm{KOH}$ occurs a new absorpation band significantly on $1300-1400 \mathrm{~cm}^{-1}$ wavenumber which is $\mathrm{Al}-\mathrm{O}$ stretching vibration absorpation. Linearity of band intensity and $\mathrm{KOH}$ concentration indicates high desilication level (zeolite silica increasing).

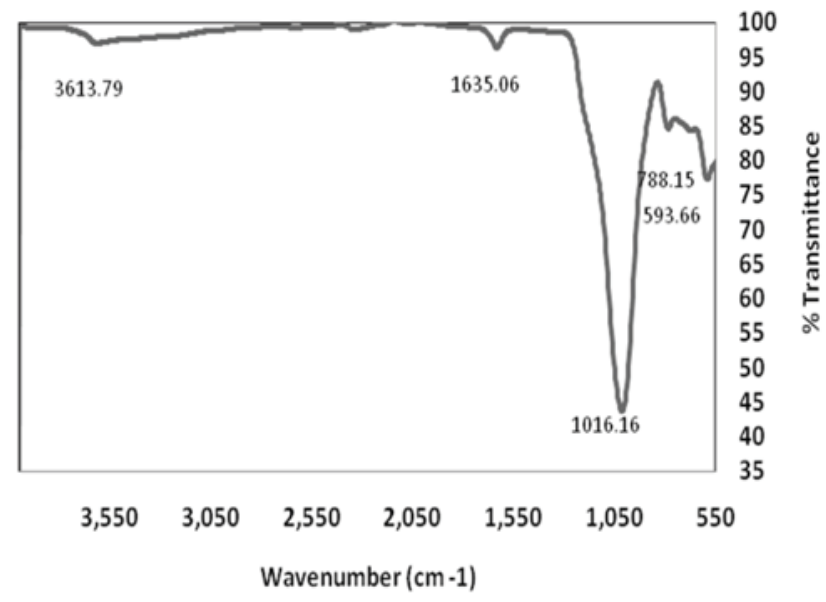

Figure 3: FTIR Spectrum of Bayah Banten Natural Zeolite

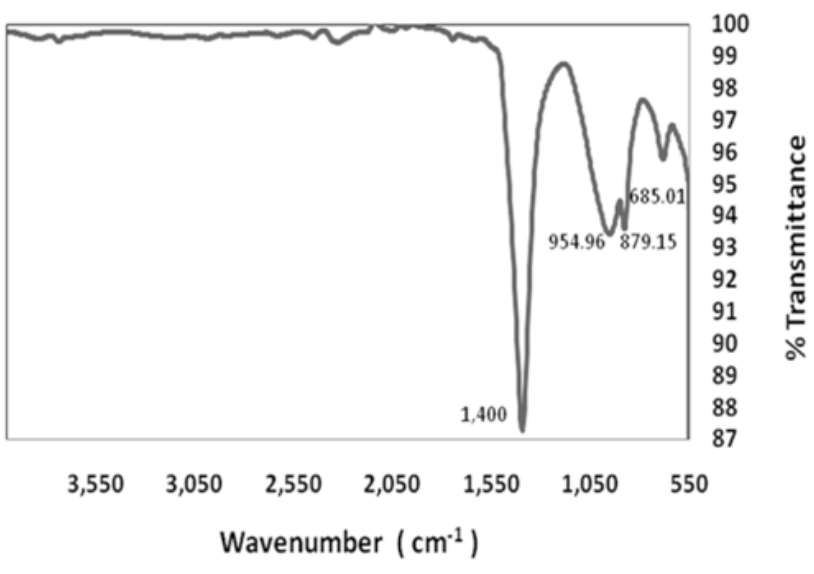

Figure 4: FTIR Spectrum of Modified Bayah Banten Natural Zeolite 


\section{SEM-EDX}

SEM-EDX analyis was conducted to find out the surface morpholygie of raw zeolite, modified zeolite and zeolite used for transesterification. Acyl SEM-EDX analysis was shown in Figure 5. The result showed that the macro structure of bayah banten natural zeolite did not change after calcination and could be concluded that zeolite has good thermal stability.

SEM-EDX analysis was performed to determine the amount of potassium in the zeolite before it was modified and after modification. The results showed an increase in the element of potassium in the zeolite after the modification process. It showed that the impregnation process of $\mathrm{KOH}$ into the surface of the zeolite occured perfectly.

Table 2: Potassium Content of Zeolite Based on SEM-EDX Analysis

\begin{tabular}{|c|c|}
\hline Catalyst & K (\% wt.) \\
\hline Bayah Banten Natural Zeolite & 23 \\
\hline Modified Bayah Banten Natural Zeolite & 59.8 \\
\hline
\end{tabular}
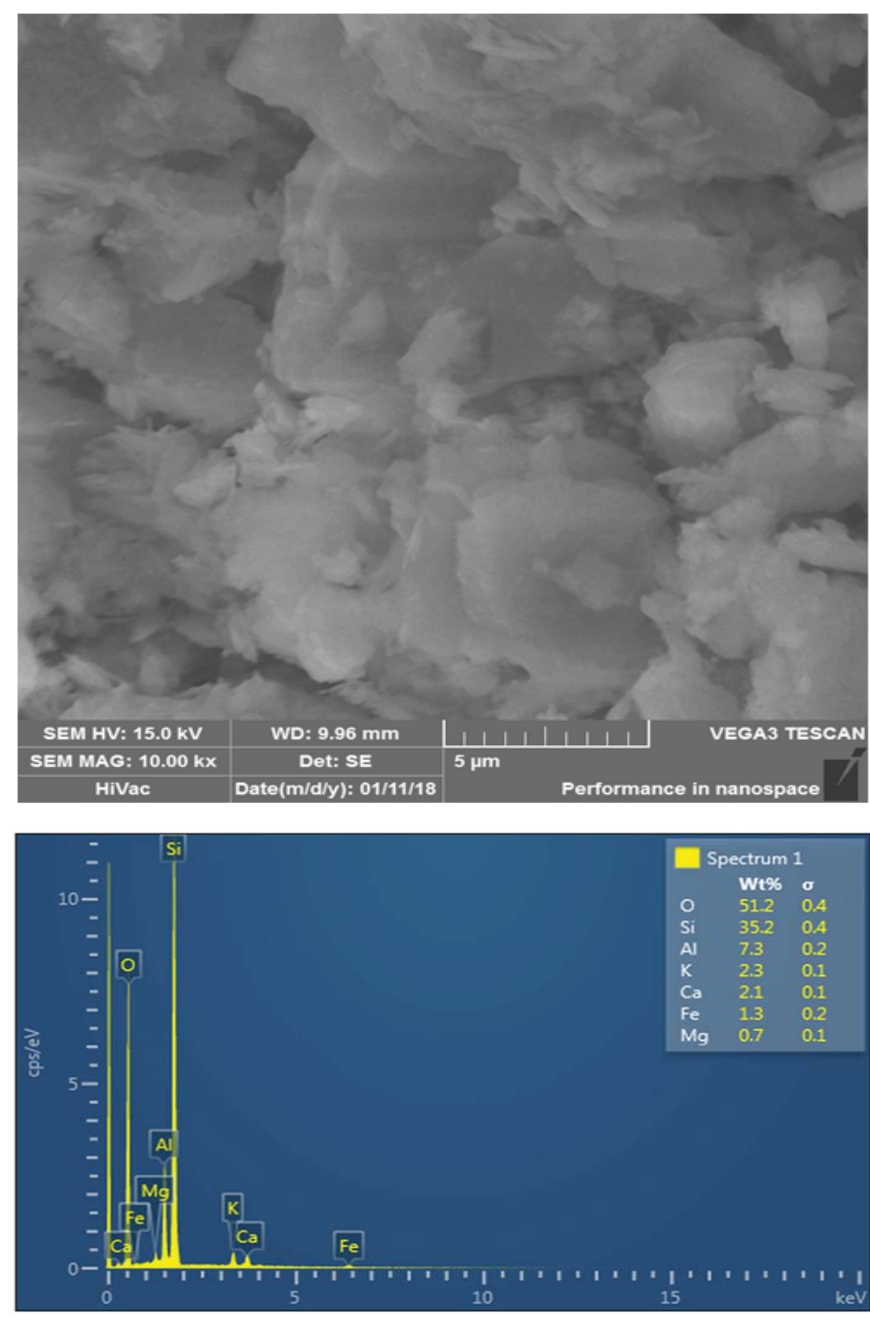

(a)

\section{The Effect of various temperature, time, and catalyst concentration toward \% yield biodiesel}

Figure 6. shows the optimum condition was obtained at the temperature variation toward produced biodiesel was at temperature of $60^{\circ} \mathrm{C}$ with 2-hour reaction time. At catalyst concentrations of $50 \mathrm{gram} \mathrm{KOH} / 100 \mathrm{ml}, 75$ gram $\mathrm{KOH} / 100 \mathrm{ml}, 100$ gram $\mathrm{KOH} / 100 \mathrm{ml}$ ), resulted biodiesel of $94 \%, 87,8 \%, 86 \%$ respectively. After passing optimum temperature, the yield of biodiesel was reduced for each particular optimum condition, figure (a), (b) and (c). Temperature has an important role to produce quality of biodiesel products. The reaction temperature did not exceed the boiling point of methanol, because when the methanol evaporates at the time of the resulting biodiesel yield reduced, if methanol gets less volume in the reaction due to evaporation, the transesterification rate reaction between the cooking oil and methanol was slow. However the length of reaction time as could be seen above, there was an optimum point, and after passing through the optimum point that causes the reaction, it will return to the beginning so that the product obtained could be reformed into reactants.
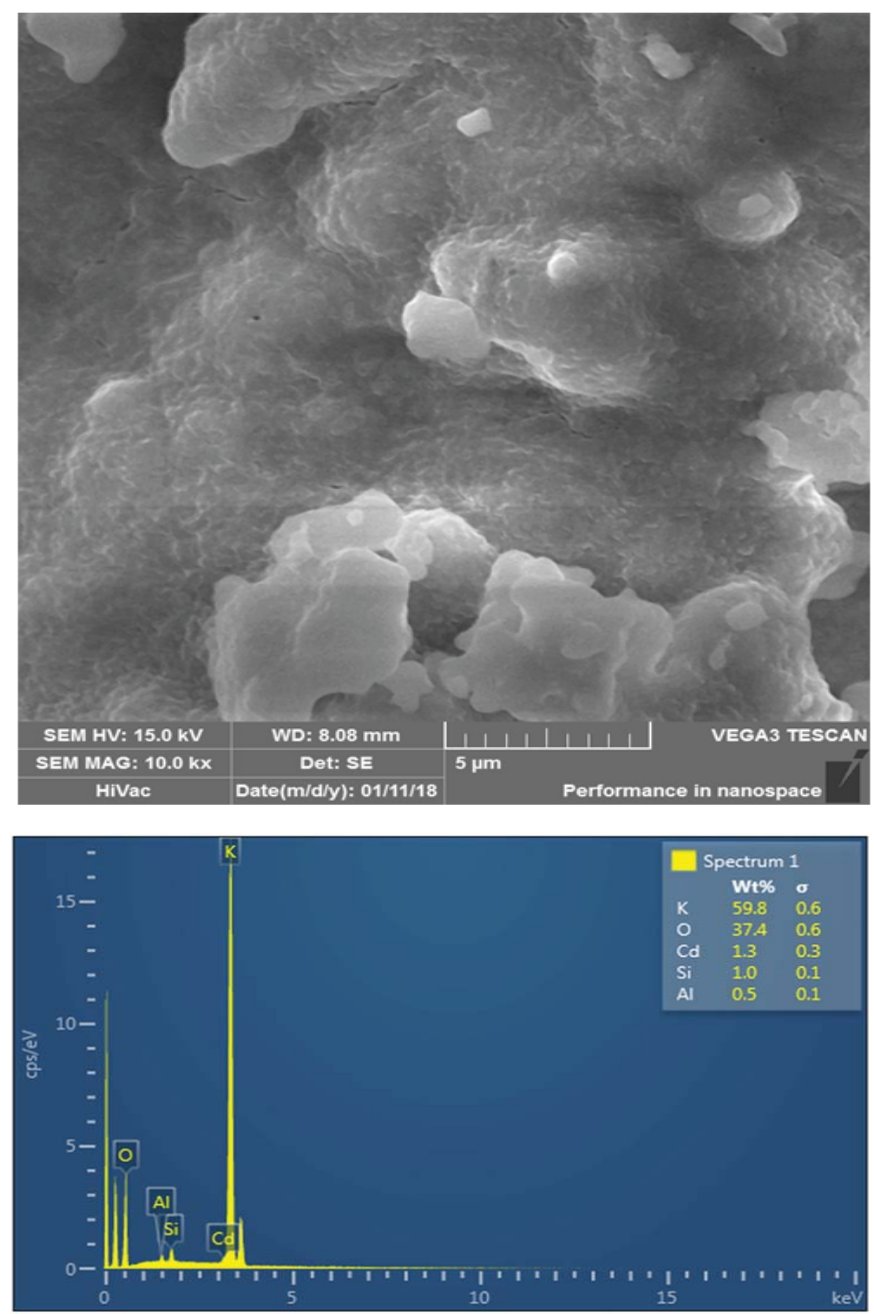

(b)

Figure 5: (a) SEM-EDX of Bayah Banten Natural Zeolite Catalyst, (b) Modified Zeolit 

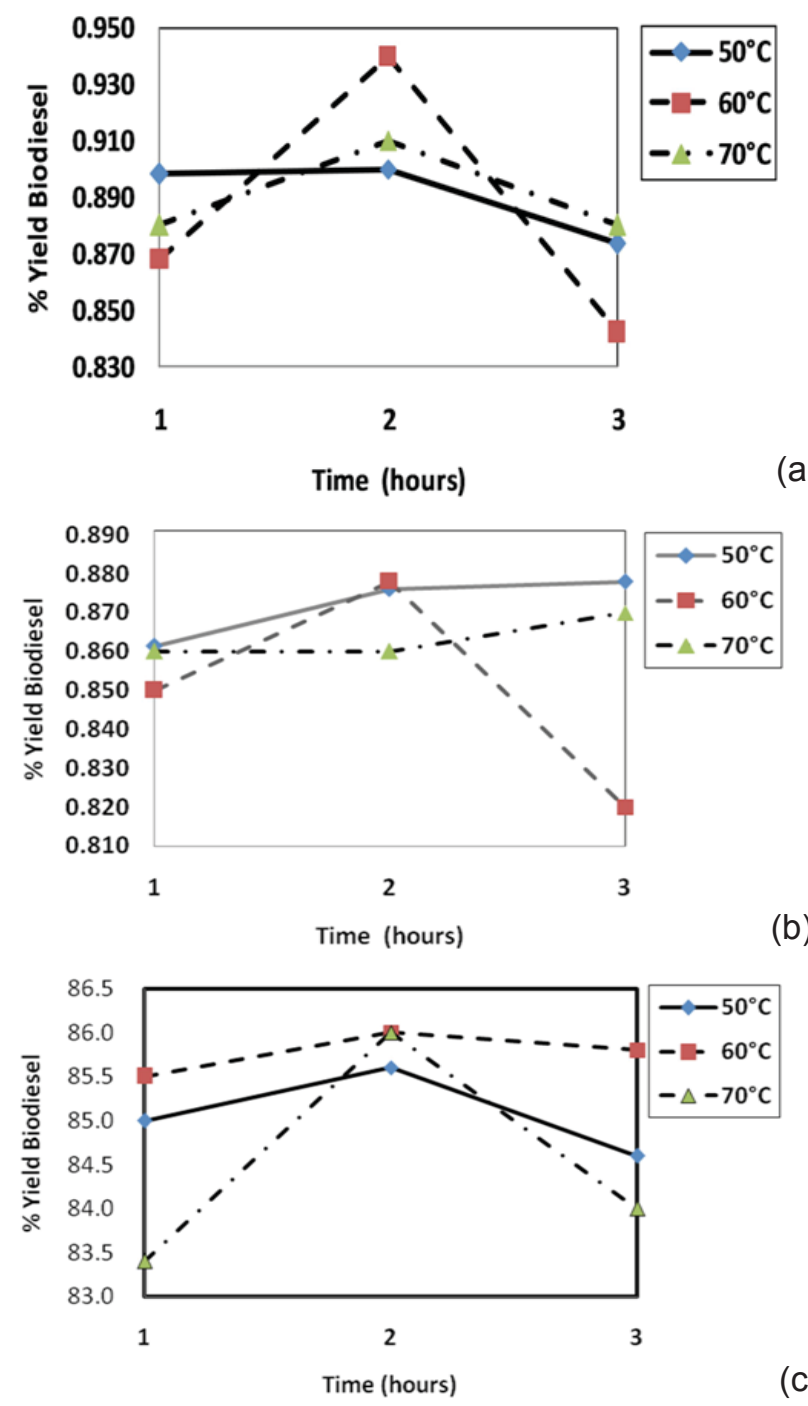

Figure 6: The Effect of Use (a) $50 \mathrm{~g} \mathrm{KOH/100ml,}$

(b) $75 \mathrm{~g} \mathrm{KOH} / 100 \mathrm{ml}$ and (c) $100 \mathrm{~g} \mathrm{KOH/100ml} \mathrm{toward}$ Biodiesel Yield

The effect of $\mathrm{KOH} / 100 \mathrm{ml}$ gram concentration (50.75 and 100) on optimum conditions

The effect of $\mathrm{KOH} / 100 \mathrm{ml}$ gram concentration on optimum condition to \% yield biodiesel produced is shown in figure 7

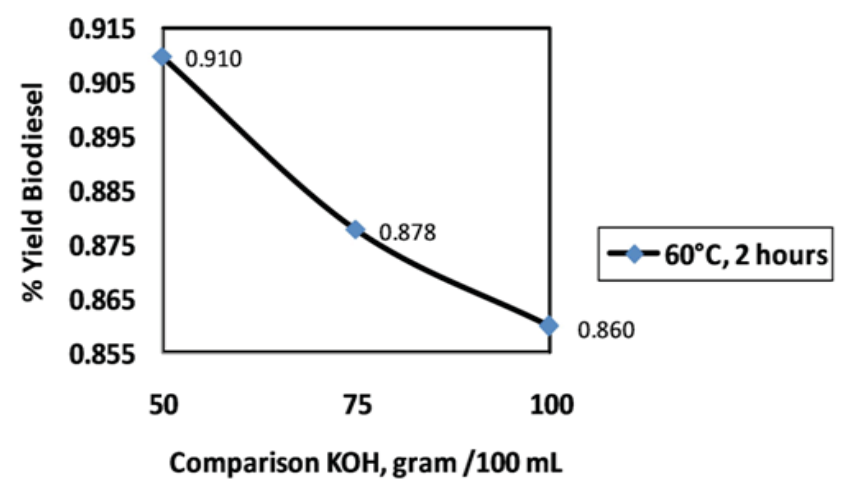

Figure 7: Optimum Condition of Biodiesel Produced
A number of modified zeolite with $\mathrm{KOH}$ concentration variations, i.e. 50 gram $\mathrm{KOH} / 100 \mathrm{ml}, 75 \mathrm{gram} \mathrm{KOH} / 100 \mathrm{ml}$, and $100 \mathrm{gram} \mathrm{KOH} / 100 \mathrm{ml}$. From figure 7, obtained results that the greater $\mathrm{KOH}$ concentration used in zeolite modification process, then the result of yield biodiesel will be declined. The more the catalyst concentration $(\mathrm{KOH})$ used will not accelerate biodiesel formation reactions and will form lathering or side reactions on experiments conducted. Content of \% Yield biodiesel on optimum conditions can be seen in Table3.

Table 3: \%Yield Biodiesel on Optimum Conditions Produced in Various Concentration (50 gram KOH/100 $\mathrm{ml}, 75 \mathrm{gram} \mathrm{KOH} / 100 \mathrm{ml}$ and $100 \mathrm{gram} \mathrm{KOH} / 100 \mathrm{ml}$ )

\begin{tabular}{|c|c|}
\hline Concentration & \% Yield \\
\hline 50 gram $\mathrm{KOH} / 100 \mathrm{ml}$ & 91,0 \\
\hline 75 gram $\mathrm{KOH} / 100 \mathrm{ml}$ & 87,8 \\
\hline 100 gram $\mathrm{KOH} / 100 \mathrm{ml}$ & 86,0 \\
\hline
\end{tabular}

\section{Metil ester content}

The content of methyl ester produced from biodiesel using a heterogeneous catalyst of Bayah Banten zeolite natural (ZAABrht) was analyzed by using GC Ester content at various concentrations shown in Figure 8.

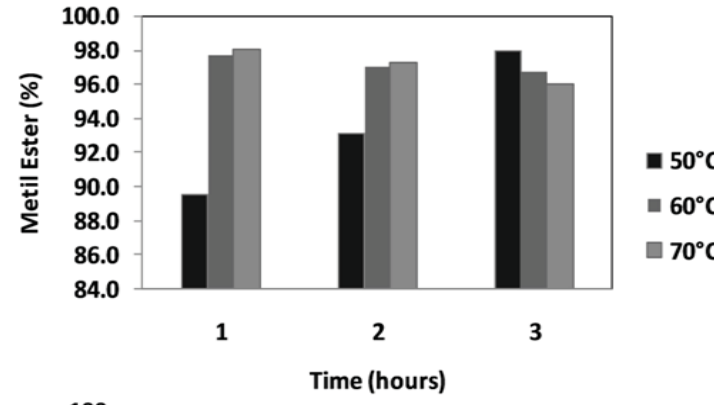

(a)

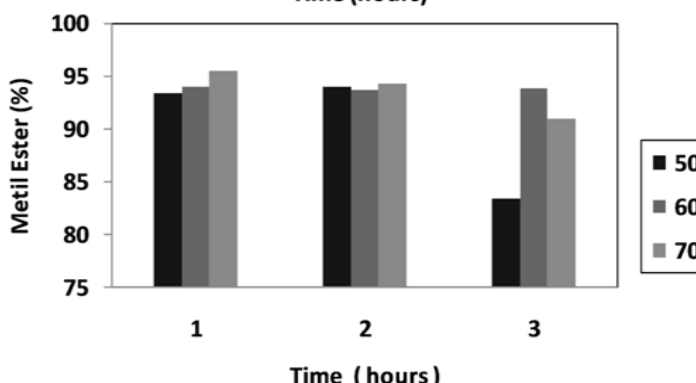

(b)

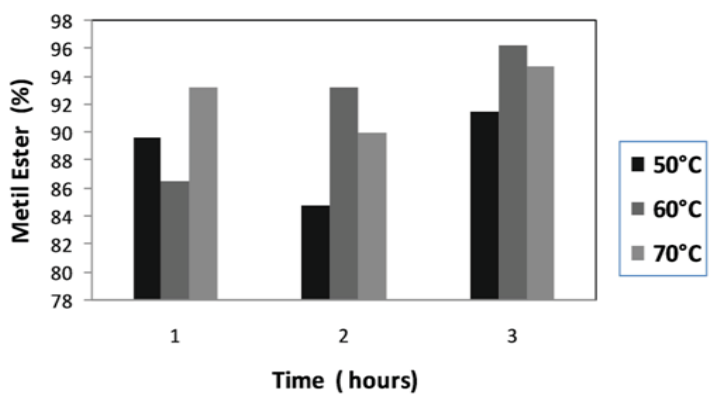

(c)

Figure 8: Methyl Ester Content in Various

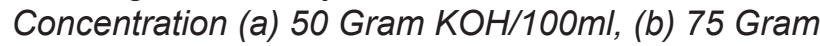
$\mathrm{KOH} / 100 \mathrm{ml}$, (c) $100 \mathrm{Gram} \mathrm{KOH/10}$ 
As shown in Figure 8 result, increasing of methyl ester number produced in $\mathrm{KOH}$ concentration that is added to temperature and time varied. In using of 50 gram $\mathrm{KOH} / 100 \mathrm{ml}$ concentration indicates the amount of methyl ester produced greater than 75 gram $\mathrm{KOH} / 100$ $\mathrm{ml}$ and 100 gram $\mathrm{KOH} / 100 \mathrm{ml}$, as described in the discussion viscosity which states the number of metoksida kalium $\left(\mathrm{K}+\mathrm{CH}_{3} \mathrm{O}\right)$ that reacts with waste cooking oil (triglycerida) so that the process of fat cluster chain cracking process higher.

Content of methyl ester greater from various concentration and time done is on the condition of 50 Gram $\mathrm{KOH} / 100 \mathrm{ml}$ at $60^{\circ} \mathrm{C}$ and 2 hours operating time. Methyl ester content produced can be seen in Table 4 .

Table 4: Methyl Ester Produced in Various Concentration (50 gram KOH/100ml, 75 gram $\mathrm{KOH} / 100 \mathrm{ml}$ and 100 gram $\mathrm{KOH} / 100 \mathrm{ml}$ )

\begin{tabular}{|c|c|}
\hline Concentration & Methyl Ester \\
\hline 50 gram $\mathrm{KOH} / 100 \mathrm{ml}$ & 97 \\
\hline 75 gram $\mathrm{KOH} / 100 \mathrm{ml}$ & 93 \\
\hline 100 gram $\mathrm{KOH} / 100 \mathrm{ml}$ & 93,2 \\
\hline
\end{tabular}

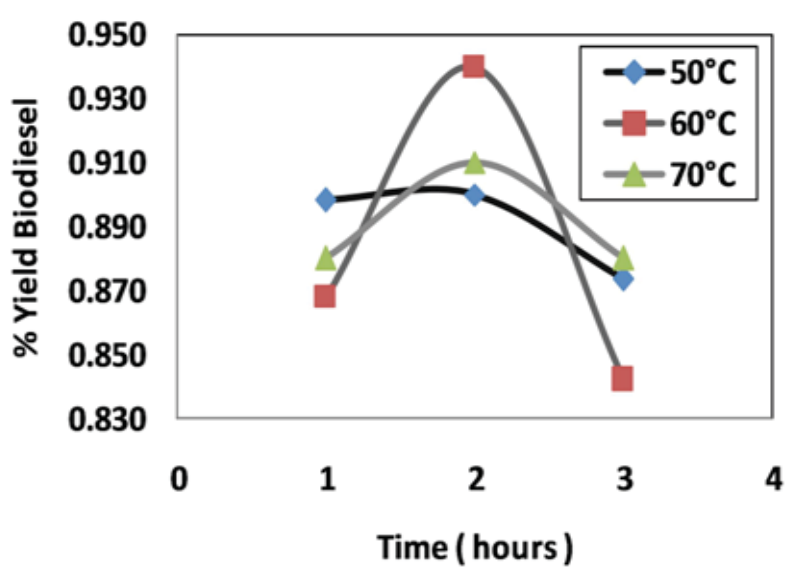

Figure 9: Transesterification Kinetics at various temperatures: $50^{\circ} \mathrm{C}, 60^{\circ} \mathrm{C}$ and $70^{\circ} \mathrm{C} .50 \mathrm{Gram}$ $\mathrm{KOH} / 100 \mathrm{ml}$

\section{Transesterification Kinetic}

The Transesterification kinetic process in this experiment was measured as a function of temperature. Temperature was varied to be range $50^{\circ}, 60^{\circ}$ and $70^{\circ} \mathrm{C}$ (Figure 9) on the use of 50 grams $\mathrm{KOH} / 100 \mathrm{ml}$. For kinetic analysis it was used equations (1) first - order reactions and equations (2) second-order reactions to represent all reaction behavior during reaction time.

$$
\begin{aligned}
& \mathrm{kt}=\ln \left(\mathrm{C}_{\mathrm{A} 0} / \mathrm{C}_{\mathrm{A}}\right) \\
& \mathrm{kt}=\left(1 / \mathrm{C}_{\mathrm{A}}-1 / \mathrm{C}_{\mathrm{A} 0}\right)
\end{aligned}
$$

(18) stated that transesterification occured based on first-order reaction equation, while [19] stated that Transesterification of catalysed alkali occurred in seccond-or- der reaction, while [20] stated that acid Transesterification occurred in first-order reactions.

To prove first or second order the calculation of reaction rate constant was carried based on FFA concentration during reaction, the determination of transesterification reaction order must be conducted based on chemical evaluation if the reaction was 1 st order, $\ln \left(\mathrm{C}_{\mathrm{A} 0} / \mathrm{C}_{\mathrm{A}}\right)$ would be linearly dependent toward 100/T (reaction temperature in Kelvin) and if the process was second order $\mathrm{C}_{\mathrm{A}}$ would be inversely propositional dependent on the value of 1000 / T. As shown in Fig. 4, the results showed that Transesterification catalyzed by the Bayah Banten natural zeolite (ZABBrht) occurred in first-order reactions, since all kinetic data curves made up the equation with high correlation $(\mathrm{R} 2=0.810)$. The second-order reaction equation was also attempted to satisfy the data, but the regression results did not correlate well $(\mathrm{R} 2=0.761)$. It could be concluded that the Transesterification process catalyzed with Bayah Banten natural zeolite (ZABBrht) in this research found to first order reaction and reaction constant rate $(k)$ based on temperature could be seen in Table 5.

Table 5: Transesterification Reaction Rate Constant
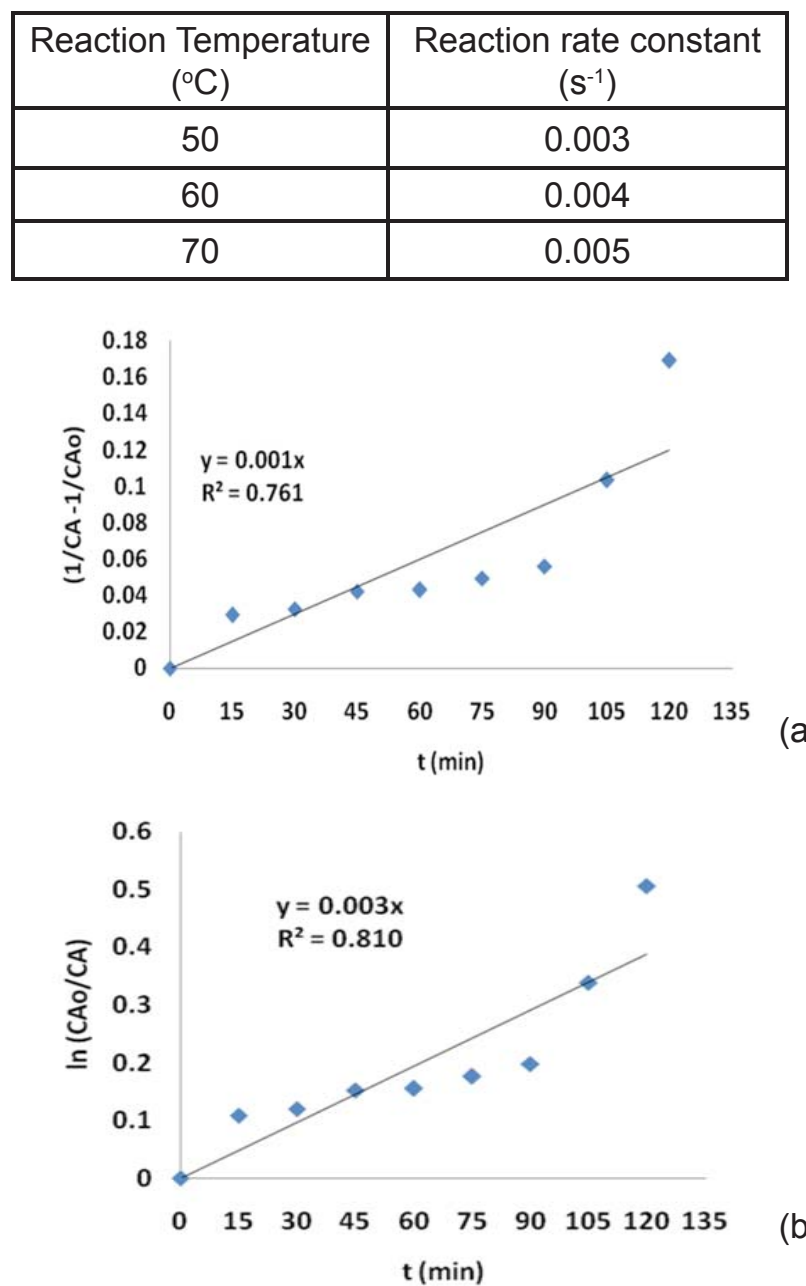

Figure 10: Kinetically Curve of the Bayah Banten (ZABBrht) 1st Order Reaction; (B) 2nd Order Reaction Transesterification Process of Natural Zeolite Catalyst 
The high temperature effects to the high reaction temperature on the rate constant of the reaction, in this study, the correlation used the Arrhenius equation (3) which was logarithmically correlated at the reaction rate constant $[\ln (k)]$ with the inverse temperature $(1 / T)$. The activation energy (Ea) of the Transesterification reaction could be calculated.

$\mathrm{k}=\mathrm{A} \exp (-\mathrm{Ea} / \mathrm{RT})$

$\ln (\mathrm{k})=\ln (\mathrm{A})-\mathrm{Ea} / \mathrm{RT}$

In which $\mathrm{R}$ is the ideal gas constant, $8.314 \mathrm{~J} / \mathrm{mol}$, A Conversion factor, seconds ${ }^{-1}$, and $\mathrm{T}$ The absolute temperature $(\mathrm{K})$

Table 6: Data for Calculating Activation Energy (Ea) and Conversion Factor

\begin{tabular}{|c|c|c|c|c|}
\hline $\begin{array}{c}\text { Reaction } \\
\text { temperature }\end{array}$ & $\mathrm{T}(\mathrm{K})$ & $1 / \mathrm{T}$ & $\mathrm{k}\left(\mathrm{s}^{-1}\right)$ & $\ln \mathrm{k}$ \\
\hline 50 & 323.16 & 0.003094 & 0.003 & -5.80914 \\
\hline 60 & 333.16 & 0.003002 & 0.004 & -5.52146 \\
\hline 70 & 343.16 & 0.002914 & 0.005 & -5.29832 \\
\hline
\end{tabular}

The correlation of $\ln (k)$ and $(1 / T)$ changed linearly with temperature of $50^{\circ}, 60^{\circ}$ and $70^{\circ} \mathrm{C}$ and obtained Activation energy ( $\mathrm{Ea}=23570,19 \mathrm{~J} / \mathrm{molK})$, Conversion Factor $(A=19.53094 / \mathrm{s})$ and the following equation was obtained.

$k=19,53094 \exp (-23570.19 / 8,314(T))$

From explanation above that the overall process has been controlled by chemical reaction.

\section{Biodiesel characteristic}

Biodiesel produced with heterogeneous $\mathrm{KOH}$ / zeolite catalyst meets ASTM as an International Standard (Table 7).

Table 7: Comparison of Biodiesel Characteristic, Research Result, and ASTM as an International Standard

\begin{tabular}{|c|c|c|}
\hline Characteristic & Research result & ASTM \\
\hline $\begin{array}{c}\text { Density at } 25^{\circ} \mathrm{C}, \\
\mathrm{kg} / \mathrm{L}\end{array}$ & 0.8629 & $\begin{array}{c}\mathrm{D} 4052 \\
(0.82-0.86)\end{array}$ \\
\hline $\begin{array}{c}\text { Kinematic viscosity } \\
\text { at } 23,4^{\circ} \mathrm{C}, \mathrm{Cst}\end{array}$ & 4.51 & $\begin{array}{c}\mathrm{D} 445 \\
(2.0-4.5)\end{array}$ \\
\hline
\end{tabular}

\section{CONLUSION}

The Bayah Banten natural zeolite that was impregnated with $\mathrm{KOH}$ could be used as a heterogeneous base catalyst to produce biodiesel by Transesterification process from waste cooking oil by Transesterification process. The optimum conditions were $60^{\circ} \mathrm{C}$ at 2 hours, reaction time with $50 \mathrm{~g} \mathrm{KOH}$ in $100 \mathrm{ml}$ of distilled water.

\section{ACKNOWLEDGEMENTS}

The author would like to thank for research support provided by Universitas Indonesia and Ministry of Research, Technology ang Higher Education Republic of Indonesia through Doctoral Dissertation Research Grant 2019.

\section{REFERENCE}

1. Đặng, T.H.; Chen, B.H.; and Lee, D.J. (2017). Optimization of biodiesel production from transesterification of triolein using zeolite LTA catalysts synthesized from kaolin clay. Journal of the Taiwan Institute of Chemical Engineers, 79,14-22.

2. Al-Jammal, N.; Al-Hamamre, Z.; and Alnaief, M. (2016). Manufacturing of zeolite based catalyst from zeolite tuft for biodiesel production from waste sunflower oil. Renewable Energy, 93,449-59.

3. Saba, T.; Estephane, J.; El Khoury, B.; El Khoury, M.; Khazma, M.; and El Zakhem, H. (2016). Biodiesel production from refined sunflower vegetable oil over KOH/ZSM5 catalysts. Renewable Energy, 90,301-6.

4. Kattimani, V.; Venkatesha, B.; and Ananda, S. (2014). Biodiesel Production from Unrefined Rice Bran Oil through Three-Stage Transesterification. Advances in Chemical Engineering and Science, 4(03), 361.

5. Zhang, Y.; Wong, W.T.; and Yung, K.F. (2013). Onestep production of biodiesel from rice bran oil catalyzed by chlorosulfonic acid modified zirconia< i> via $</ i>$ simultaneous esterification and transesterification. Bioresource technology, 147, 59-64.

6. Fereidooni, L.; Mehrpooya, M. (2017). Experimental assessment of electrolysis method in production of biodiesel from waste cooking oil using zeolite/ chitosan catalyst with a focus on waste biorefinery. Energy Conversion and Management, 147, 145-54

7. Manadee, S.; Sophiphun, O.; Osakoo, N.; Supamathanon, N.; Kidkhunthod, P.; and Chanlek, N. (2017). Identification of potassium phase in catalysts supported on zeolite $\mathrm{NaX}$ and performance in transesterification of Jatropha seed oil. Fuel Processing Technology, 156,62-7.

8. Chen, Y.C.; Lin, D.Y.; and Chen, B.H. (2017). Transesterifica tion of acid soybean oil for biodiesel production using lithium metasilicate catalyst prepared from diatomite. Journal of the Taiwan Institute of Chemical Engineers, 79, 31-6.

9. Volli, V.; and Purkait, M.K.. (2015). Selective preparation of zeolite $X$ and $A$ from flyash and its use as catalyst for biodiesel production. Journal of Hazardous Materials, 297,101-11.

10. Ma, Y., Wang, Q.; Sun, X.; Wu, C.; and Gao, Z. (2017). Kinetics studies of biodiesel production from waste cooking oil using $\mathrm{FeCl}_{3}$-modified resin as hetero geneous catalyst. Renewable Energy, 107,522-30. 
11. Kusuma, R.I.; Hadinoto, J.P.; Ayucitra, A.; Soetaredjo, and F.E.; Ismadji. S. (2013). Natural zeolite from Pacitan Indonesia, as catalyst support for transesterific ation of palm oil. Applied Clay Science, 74(0),121-6.

12. Evangelista, J.P.; Chellappa, T.; Coriolano, A.C.; Fernandes, Jr. VJ.; Souza, L.D.; and Araujo, A.S. (2012).Synthesis of alumina impregnated with potassium iodide catalyst for biodiesel production from rice bran oil. Fuel Processing Technology, 104,90-5.

13. Olutoye, M.A.; and Hameed. B.H. (2013). Production of biodiesel fuel by transesterification of different vegetable oils with methanol using $\mathrm{Al} 2 \mathrm{O} 3$ modified MgZnO catalyst. Bioresource Technology, 132(0),103-8.

14. Xie, W.; and Huang X, Li. H. (2007).Soybean oil methyl esters preparation using NaX zeolites loaded with $\mathrm{KOH}$ as a heterogeneous catalyst. Bioresource Technology, 98(4),936-9.

15. Chung, K.H.; Chang, D.R.; and Park, B.G. (2008). Removal of free fatty acid in waste frying oil by esterification with methanol on zeolite catalysts. Bioresource Technology, 99(16),7438-43.
16. Hartono, R.; Wijanarko, A. And Hermansyah, H. (2018). Synthesis of biodiesel using local natural zeolite as heterogeneous anion exchange catalyst. IOP Conference Series: Materials Science and Engineering, 345(1),012002.

17. Noiroj, K.; Intarapong, P.; Luengnaruemitchai, A.; and Jai-In, S. (2009). A comparative study of $\mathrm{KOH} /$ $\mathrm{Al} 2 \mathrm{O} 3$ and $\mathrm{KOH} / \mathrm{NaY}$ catalysts for biodiesel production via transesterification from palm oil. Renewable Energy, 34(4),1145-50

18. Li, J.; Fu, Y.J.; Qu, X.J.; Wang, W.; Luo, M.; and Zhao, C.J. (2012). Biodiesel production from yellow horn (Xanthoceras sorbifolia Bunge.) seed oil using ion exchange resin as heterogeneous catalyst. Bioresource Technology, 108(0),112-8.

19. Darnoko, D.; and Cheryan, M. (2000). Kinetics of palm oil transesterification in a batch reactor. Journal of the American Oil Chemists' Society, 7(12),1263-7.

20. Freedman, B.; Pryde, E.; and Mounts, T. (1984). Variables affecting the yields of fatty esters from transesterified vegetable oils. Journal of the American Oil Chemists Society, 61(10),1638-43. 